\title{
Manufacturing and banking canine adipose-derived mesenchymal stem cells for veterinary clinical application
}

\author{
Huina Luo ${ }^{1 \dagger}$, Dongsheng $\mathrm{Li}^{2 \dagger}$, Zhisheng Chen ${ }^{1}$, Bingyun Wang ${ }^{1 *}$ and Shengfeng Chen ${ }^{1 *}$
}

\begin{abstract}
Background: Mesenchymal stem cells (MSCs) have generated a great amount of interest in recent years as a novel therapeutic application for improving the quality of pet life and helping them free from painful conditions and diseases. It has now become critical to address the challenges related to the safety and efficacy of MSCs expanded in vitro. In this study, we establish a standardized process for manufacture of canine adipose-derived MSCS (ADMSCs), including tissue sourcing, cell isolation and culture, cryopreservation, thawing and expansion, quality control and testing, and evaluate the safety and efficacy of those cells for clinical applications.

Results: After expansion, the viability of AD-MSCs manufactured under our standardized process was above $90 \%$. Expression of surface markers and differentiation potential was consistent with ISCT standards. Sterility, mycoplasma, and endotoxin tests were consistently negative. AD-MSCs presented normal karyotype, and did not form in vivo tumors. No adverse events were noted in the case treated with intravenously AD-MSCs.

Conclusions: Herein we demonstrated the establishment of a feasible bioprocess for manufacturing and banking canine AD-MSCs for veterinary clinical use.
\end{abstract}

Keywords: Canine, Cell therapy, Mesenchymal stem cells, Adipose, Banking

\section{Background}

Mesenchymal stem cells (MSCs) which were first discovered by Friedenstein from bone marrow derived cells are a type of self-renewing cells harboring the potential to differentiate into diverse tissues, such as bone, cartilage, muscle, fat and tendon [1-5]. At present, in human clinical medicine, a variety of clinical trials with human MSCs are ongoing for the treatment of immunological diseases and degenerative diseases [6-9]. Currently, it has been reported that MSCs could be isolated from various tissues other than bone marrow [10], such as adipose [11], umbilical cord [12], dental pulp [13],

\footnotetext{
*Correspondence: bywang63@163.com; yixu77@163.com

${ }^{\dagger}$ Huina Luo and Dongsheng Li contributed equally to this work.

${ }^{1}$ School of Life Science and Engineering, Foshan University, 528231 Foshan, Guangdong, China

Full list of author information is available at the end of the article
}

placenta [14] and amniotic membrane [15]. Adiposederived Mesenchymal stem cells (AD-MSCs) have gained in popularity due to the ease and abundance of harvesting adipose tissue, greater capacity of self-renewal multipotency and paracrine immunomodulatory [11, 16-18].

As one of the most common companion animals, some breeds of canine including beagles are also experimental animals. With the improvement of living standards, diseases of aging in canine have become more common clinically, especially chronic diseases, such as osteoarthritis, hip dysplasia, diabetes, pancreatitis and tendonopathy [19, 20]. Meanwhile, there are no particularly effective treatments for these diseases, which not only affect the quality of life of the affected animals, but also require the owners to invest a lot of energy, time and money. Currently, many related reports have confirmed that AD-MSCs therapy in

\section{$\triangle B M C$}

(c) The Author(s). 2021 Open Access This article is licensed under a Creative Commons Attribution 4.0 International License, which permits use, sharing, adaptation, distribution and reproduction in any medium or format, as long as you give appropriate credit to the original author(s) and the source, provide a link to the Creative Commons licence, and indicate if changes were made. The images or other third party material in this article are included in the article's Creative Commons licence, unless indicated otherwise in a credit line to the material. If material is not included in the article's Creative Commons licence and your intended use is not permitted by statutory regulation or exceeds the permitted use, you will need to obtain permission directly from the copyright holder. To view a copy of this licence, visit http://creativecommons.org/licenses/by/4.0/ The Creative Commons Public Domain Dedication waiver (http://creativecommons.org/publicdomain/zero/1.0/) applies to the data made available in this article, unless otherwise stated in a credit line to the data. 
a variety of canine diseases in clinical trials have shown initial results [21-25].

As one kind of superior cytotherapy, canine AD-MSCs therapy has great clinical application potential in various chronic diseases treatment [26, 27]. Although the technology of canine AD-MSCs isolation and expansion at laboratory scale is relatively mature, manufacturing a therapeutic cell-based product is and will continue to be challenging $[28,29]$. In this paper, we established a standardized operating procedure for manufacturing canine AD-MSCs, which encompasses tissue sourcing, cell isolation and culture, cryopreservation, thawing and expansion, quality control and testing, and evaluate the safety and efficacy of those cells for clinical applications. The establishment of canine AD-MSCs bank was expected to provide an adequate source of seed cells for the cell therapy of canine diseases and the research of tissue engineering products.

\section{Result}

\section{Cell isolation,culture and cryopreservation}

Approximately $2-6 \times 10^{6}$ nucleated cells were obtained from adipose tissue ( $n=12$, range $2-5$ grams) after collagenase type I digestion and seeded into $1-2100 \mathrm{~mm}$ cell -culture dishes. After $48 \mathrm{~h}$ of growth, the vast majority of AD-MSCs were attached to the culture plate and exhibited fibroblast-like morphology (Fig. 1). The cells grew to $80 \%-90 \%$ confluence after 5-7 days and were passaged for the first time. After second passages with a 1:3 split ratio, $0.64-2.67 \times 10^{7}$ AD-MSCs passage 2 were harvested and cryopreserved at the end of first expansion period. Each batch of AD-MSCs must passed the in-process test and be given a unique identifier before cryopreservation. Viability of the freshly harvested cells was greater than $90 \%$ in all cases. Basic data for the MSC expansions are shown in Table 1.

\section{Characterization and quality controls}

AD-MSCs presented subsequently fibrous or fusiform shape and showed fibroblast-like adherent growth (Fig. 1).

The Cells of passage 2 and passage 5 were highlyexpressed mesenchymal stem cell surface markers CD29, CD44 and CD90, while for the lowly-expressed haematopoietic stem cells surface markers CD34 and leukocyte common antigen CD45. The positive expression rate for CD29, CD44 and CD90, in was $>95 \%$, and the positive expression rate for CD34 and CD45 was $<2 \%$ (Table 2; Fig. 2).

The ability of adipogenic, osteogenic and chondrogenic differentiation in vitro was detected respectively by Oil red $\mathrm{O}$, alizarin red and alcian blue staining. The adipogenic differentiated AD-MSCs were visualized by
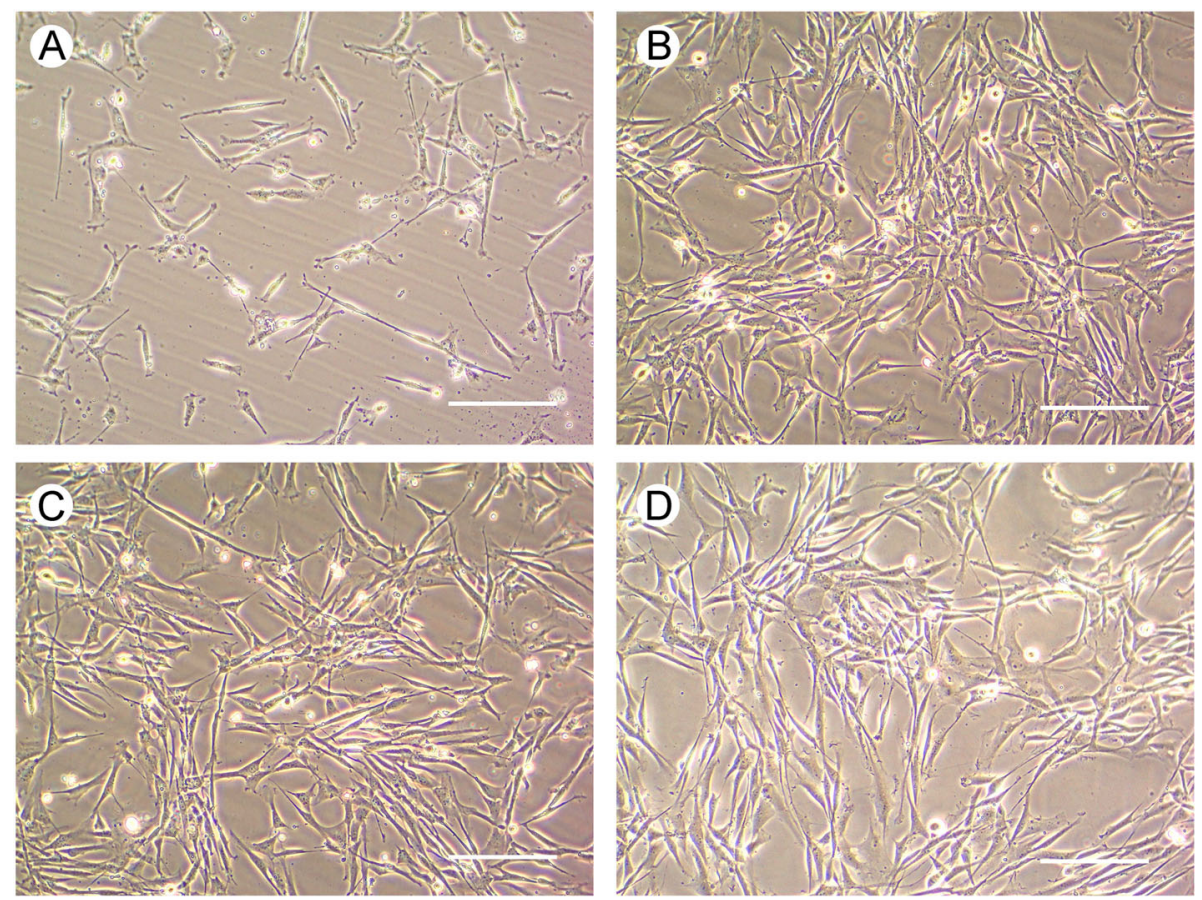

Fig. 1 Morphological observations of canine AD-MSCs in different generations. a Canine AD-MSCs on day 4 of primary culture. Adherent spindle cells appeared and most of the other suspension cells died and disappeared; (b and c) Morphology of canine AD-MSCs in passage 1 and passage 2, respectively. Cells were very pure and homogeneous with a typical long spindle-shape. $\mathbf{d}$ Morphology of thawed canine AD-MSCs in passage 4 . Cell morphology and proliferation ability were maintained after cryopreservation. Scale bar, $200 \mu \mathrm{m}$ 
Table 1 The number of harvested cells in different passages

\begin{tabular}{lcccc}
\hline No. & Size $(\mathbf{g})$ & Harvested Cells of P0 $\left(\mathbf{1 0}^{\mathbf{6}}\right)$ & Harvested Cells of P1 $\mathbf{( 1 \mathbf { 0 } ^ { \mathbf { 6 } } )}$ & Harvested Cells of P2 $\mathbf{( 1 \mathbf { 0 } ^ { \mathbf { 6 } } )}$ \\
\hline CAD-001 & 3.2 & 3.7 & 10.5 & 26.7 \\
CAD-002 & 4.1 & 4.2 & 12.3 & 24.3 \\
CAD-003 & 2.1 & 2.2 & 4.1 & 7.8 \\
CAD-004 & 2.4 & 4.3 & 8.3 & 17.3 \\
CAD-005 & 3.2 & 3.2 & 4.7 & 9.3 \\
CAD-006 & 3.2 & 4.1 & 9.2 & 10.4 \\
CAD-007 & 4.5 & 4.7 & 12.2 & 26.7 \\
CAD-008 & 1.2 & 4.3 & 8.9 & 19.2 \\
CAD-009 & 1.9 & 3.0 & 6.4 & 12.6 \\
CAD-010 & 2.4 & 4.1 & 9.4 & 19.9 \\
CAD-011 & 6.1 & 5.8 & 10.7 & 23.5 \\
CAD-012 & 3.1 & 5.9 & 12.7 & 25.9 \\
\hline
\end{tabular}

staining with Oil red-O on day 15. Calcium nodules were observed and stained red by alizarin red in osteogenic induction groups on day 17. Representative of chondrogenic differentiation detected by alcian blue staining at day 28 (Fig. 3).

The population doubling time and Colony-Forming unit-fibroblasts capacity of AD-MSCs was used to assess proliferative ability. The population doubling time was $22.03 \pm 2.30$ hours in passage 2 and $23.62 \pm 1.67$ hours in passage 5 . The Colony-Forming unit-fibroblasts capacity of AD-MSCs of in passage 2 and passage 5 were $15.20 \pm$ $2.77 \%$ and $16.20 \pm 3.70 \%$, respectively (Fig. 4).

Sterility, mycoplasma, and endotoxin test were performed before cryopreservation and release of final product, as well as by random testing of culture supernatants in the course of the expansion. All the precryopreservation cells and final products were free of microbial and mycoplasma contamination. Endotoxin levels of pre-cryopreservation cells and final products were lower than $0.5 \mathrm{EU} / \mathrm{ml}$.

AD-MSCs were diploid, containing 78 chromosomes and no abnormalities were detected (Fig. 5). No evidence of tumor formation of observation in mice and the skin at the site of AD-MSCs injection did not contain residual detectable tumor cells, as noted by histopathology (Fig. 6).

Table 2 Surface marker expression of AD-MSCS

\begin{tabular}{lrr}
\hline $\begin{array}{l}\text { Surface } \\
\text { marker }\end{array}$ & Expression (\%) & \\
\cline { 2 - 3 } & \multicolumn{1}{c}{ Passage 2 } & Passage 5 \\
\hline CD 29 & $99.35 \pm 0.48$ & $99.25 \pm 0.59$ \\
CD 34 & $0.18 \pm 0.06$ & $0.29 \pm 0.31$ \\
CD 44 & $99.22 \pm 0.59$ & $98.27 \pm 0.73$ \\
CD 45 & $0.47 \pm 0.38$ & $0.54 \pm 0.28$ \\
CD 90 & $98.32 \pm 0.99$ & $98.08 \pm 1.43$ \\
\hline
\end{tabular}

\section{Cell therapy}

The case showed an unexpected response to stem cell therapy. After intravenous transplantation of AD-MSCs, the spirit state of the infected dog improved on the day of treatment, and the number of white blood cells increased on the second day and returned to normal on the third day (Table 3). Control group case had no obvious improvement, and the number of white blood cells were extremely low and neutrophils were reduced to undetectable levels on the second day. And eventually, the control group dog died on the third day. In general, stem cell therapy combined with conventional treatment of canine parvovirus infection has the advantages of rapid cure, short course of treatment, good effect, and no adverse reactions. There were no adverse reactions in response to AD-MSCs therapy.

\section{Discussion}

AD-MSCs are a type of adult stem cell deriving from adipose tissues with self-renewal ability and multidirectional differentiation potential [30]. As an attractive source of MSCs, adipose tissue usually contains far more MSCs than other sources contain [31]. ADMSCs have become the focus of considerable interest in regenerative tissue engineering due to their easy access and availability in large quantities. The different methods for isolation and culture of canine ADMSCs has also been established across different countries and different laboratories [22, 24, 26]. Currently, MSCs manufacture including isolation, culture and identification methods are labor intensive, with many time-consuming steps $[3,32]$. A complex set of processes introduces the risk of microbial infection and changes in biologic properties [33]. Accordingly, all steps of cell manufacture for clinical application must be performed based on good manufacturing practice to achieve a reasonable safety and quality [34]. The 


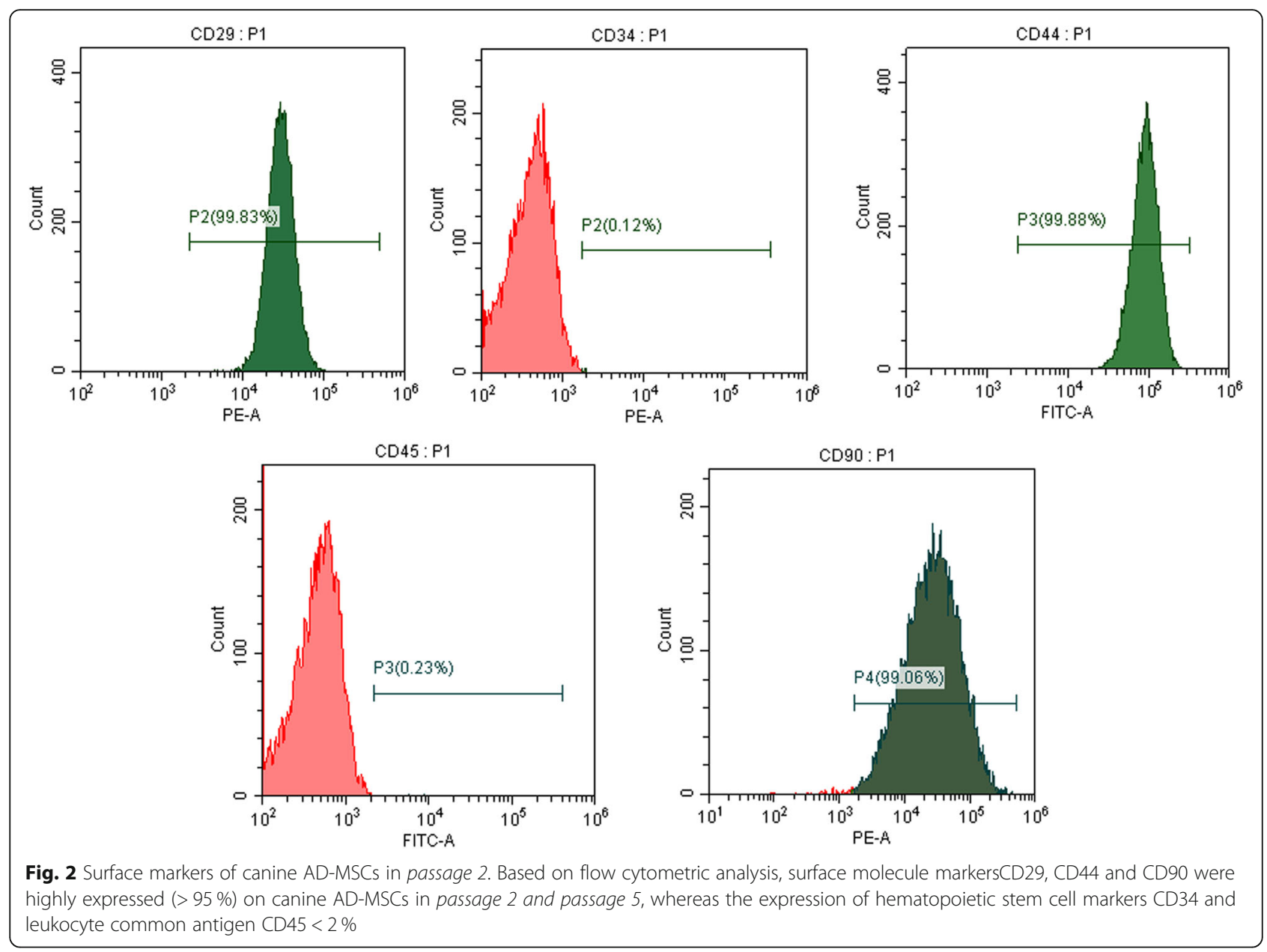

establishment of canine AD-MSCs bank operating in accordance with good manufacturing practice standards will accelerates the clinical application of canine stem cell therapy and the development of stem cell industrialization in pet market.
In this study, we tried to establish a standardized operating process encompasses tissue sourcing, cell isolation and culture, cryopreservation, thawing and expansion for clinical grade canine AD-MSCs manufacturing. Adipose tissue samples were aseptically collected from
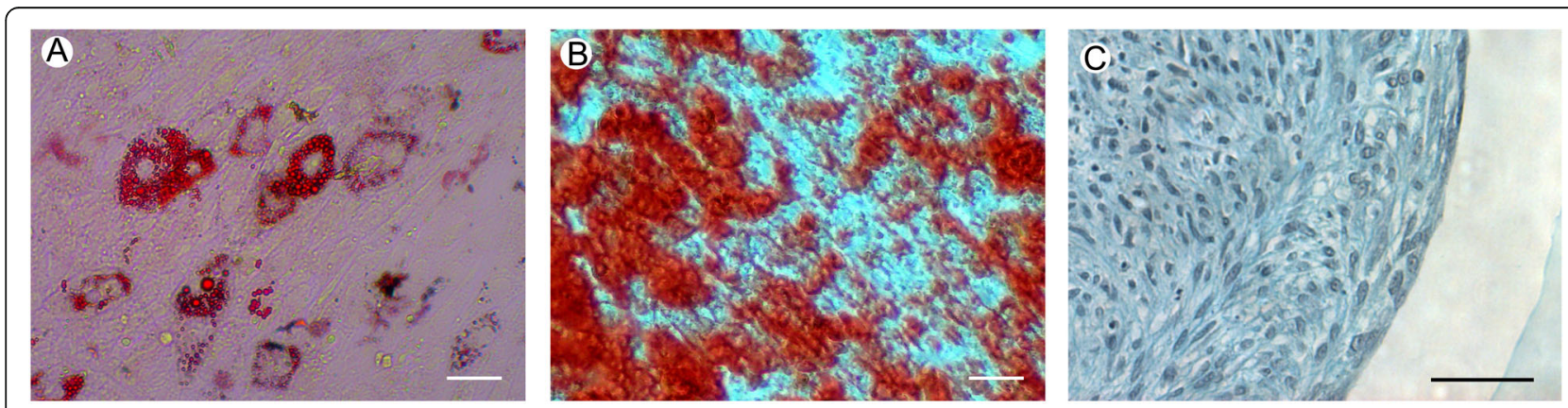

Fig. 3 Adipogenic, osteogenic and chondrogenic differentiation of canine AD-MSCs in passage 2. a Following adipogenic induction for 14 days, canine AD-MSCs were positive for Oil red-O staining and contained an abundance of lipid droplets. $\mathbf{b}$ Following osteogenic induction for 14 days, canine AD-MSCs in were positive for alizarin red staining. c Following chondrogenic induction for 21 days, canine AD-MSCs in were positive for alcian blue staining. Scale bars, $50 \mu \mathrm{m}$ 

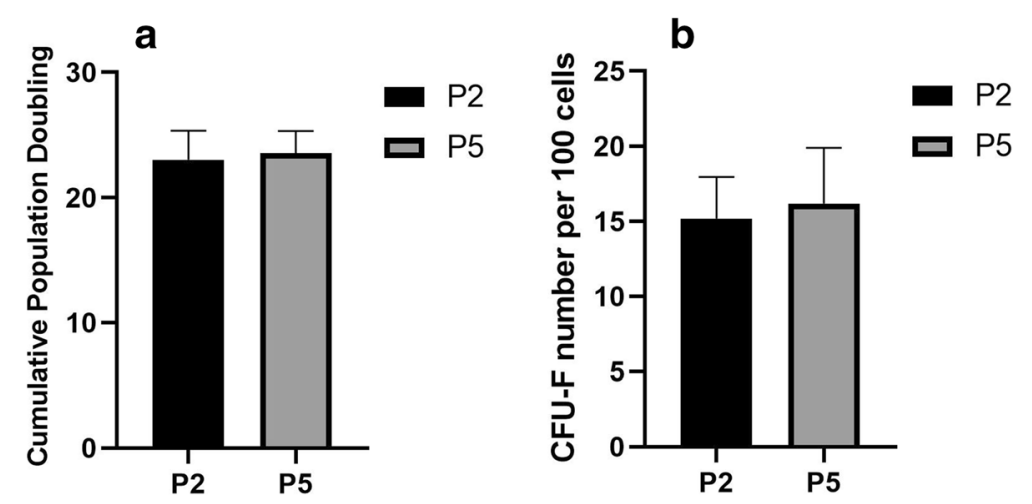

Fig. 4 Growth characteristics of canine AD-MSCs in passage 2 and passage 5. a cumulative population doubling and $\mathbf{b}$ Colony-Forming unitfibroblasts capacity in passage 2 and passage 5. ${ }^{*} \mathrm{P}<0.05$. CFU-F, Colony-Forming unit-fibroblasts capacity. P2, passage 2; P5, passage 5

abdomen fat of healthy donor canine under general anaesthesia. Donor canine peripheral blood was then taken for the examination of infectious diseases including RV, $\mathrm{CDV}$, ICHV, CPV, CCV, fungi and bacteria. Subsequent process can be carried out after the qualification is confirmed, which will serve as the initial basis for the study of cell quality. Using mechanical disruption combined with collagenase type I digestion, AD-MSCs could be successfully isolated and further seeded centrifugally into cell culture dishes in our optimum culture conditions.

After thawing and expansion, AD-MSCs showed all properties characteristic for mesenchymal stem cells outlined by the International Society for Cellular Therapy (ISCT) for defining MSCs [35]. The cells were in a fibrocyte-like form and had a spindle-shape, and were arranged in a whirlpool pattern. The cells formed a monolayer of homogenous bipolar spindlelike cells with a whirl-pool-like array. The immunophenotype analysis displayed that the cells positively expressed of CD29, CD44, and CD90 and the lack of CD34, and CD45. In addition, they demonstrated the ability of osteogenic, chondrogenic and adipogenic differentiation.

The manufacturing of AD-MSCs as cell therapy products for veterinary clinical application should be performed with corresponding controls to ensure its safety and quality [36, 37]. The AD-MSCs have undergone safety testing including sterility, and mycoplasma and results found to meet specifications. There were no bacterial, fungal, or mycoplasma contaminations observed in any of our 12 cultures. The passaged AD-MSCs maintained normal karyotype and had no evidence of tumorigenicity. With a small number of cells and a limited number of injections, the administration of AD-MSCs was demonstrated intravenously without any immediate adverse events.

In comparison with stem cells derived from other sources, AD-MSCs have the advantages of convenient material acquisition, fewer ethical issues, low damage and abundant sources [38, 39]. Our previous study indicated that canine AD-MSCs had the highest proliferation activity vis-à-vis four other sources-derived MSCs in vitro. On average, the number of AD-MSCs doubled every day in our cell culture system [40]. The higher rates of cell proliferation help to harvest more numbers of MSCs in the same unit of time, thus saving cell production costs and times. In addition, the establishment of AD-MSCs banks may accelerate the veterinary clinical application of stem cell therapy and the development of pet stem cell businesses.

\section{Conclusions}

In summary, we successfully established a standardized process for manufacturing and banking canine ADMSCs for clinical use and confirmed adipose tissues representing an appealing source of MSCs for cell therapy. It is hoped that the clinical experimental research and application of canine $\mathrm{AD}-\mathrm{MSC}$ in regenerative medicine will benefit the majority of sick animals and contribute to the health of pet dogs.

\section{Materials and methods}

\section{Adipose tissue collection}

Canine abdominal subcutaneous adipose was collected during routine clinically indicated surgery at Affiliated Animal Hospital of Foshan University from 2017 to 2019. All owners agreed with the collection of tissue and signed an informed consent. A screen of the medical history was performed and a blood sample was tested for specific canine pathogens, such as rabies virus (RV), canine distemper virus (CDV), infectious canine hepatitis virus (ICHV), canine parvovirus (CPV), canine coronaviruses (CCV), fungi and bacteria. Tissue collection was approved by the Animal Ethics Committee of Foshan University, and were conducted in accordance with the ethical standards of the university. Adipose tissue 


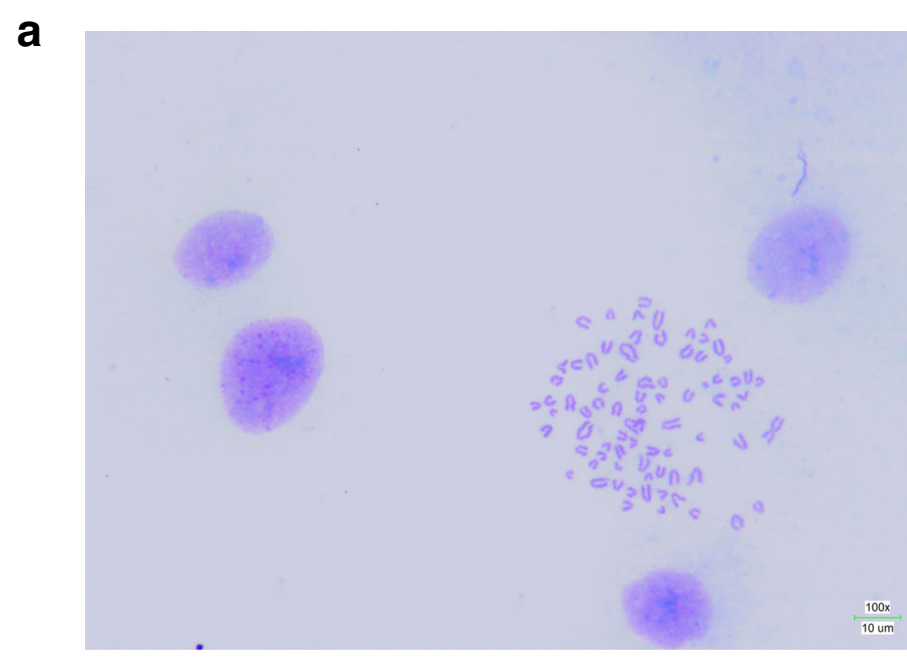

b

核型分析图
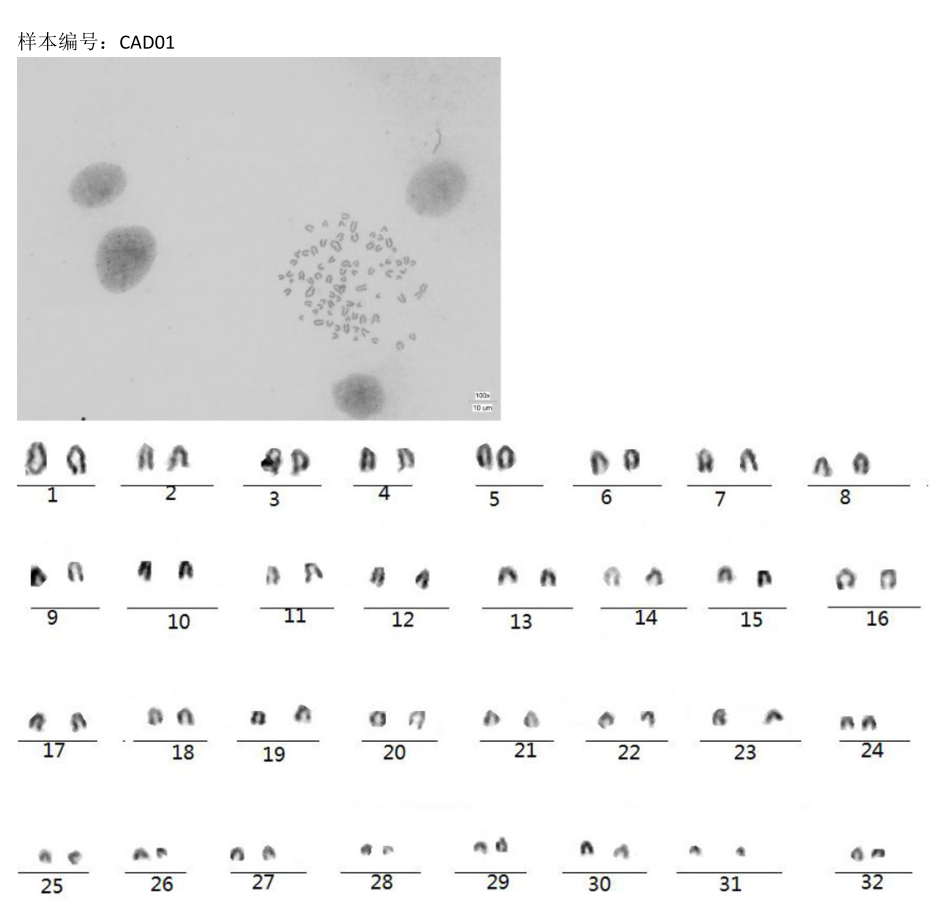

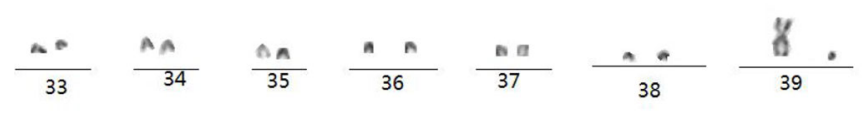

分析结果: $2 n=78$ 分析日期: 20201208

检测人: 左智文

备注: 2 倍体核型

Fig. 5 Chromosome and Karyotype analysis of canine AD-MSCs in passage 5. a Metaphase chromosome analysis (magnification: $\times 1,000$ ) and $\mathbf{b}$ karyotype analysis of AD-MSCs. The number of chromosomes in the AD-MSCs was containing 38 pairs of euchromosomes plus two sex chromosomes (XY)

immersed in DMEM (Hyclone, USA) supplemented 1\% penicillin and streptomycin (Gibco, USA) immediately transported to the lab at $4-10^{\circ} \mathrm{C}$.

\section{Cell isolation and culture}

MSCs were isolated from adipose tissue based on methods previously described [40]. Briefly, tissue was 
Table 3 Hemogram levels before and after AD-MSCs transplantation treatment

\begin{tabular}{lllcr}
\hline & Prior Treatment & 2 d after Treatment & 3 d after Treatment & Reference Range \\
\hline $\operatorname{WBC}\left(10^{9} / \mathrm{L}\right)$ & 0.9 & 1.1 & 7.3 & $6.0-17.0$ \\
$\operatorname{Lym}\left(10^{9} / \mathrm{L}\right)$ & 0.2 & 0.4 & 2.5 & $5.1-10.8$ \\
$\operatorname{Mon}\left(10^{9} / \mathrm{L}\right)$ & 0 & 0 & 0.4 & $0-1.8$ \\
$\operatorname{Gran}\left(10^{9} / \mathrm{L}\right)$ & 0.7 & 0.7 & 4.4 & $4.0-12.6$ \\
\hline
\end{tabular}

WBC white blood cell, Lym lymphocyte, Mon monocyte, Gran granulocyte

digested with collagenase type I. Then filtration through a 100-mesh cell strain, the filtrate was centrifuged to collect AD-MSCs. Approximately 5000 isolated suspended cells per $\mathrm{cm}^{2}$ were transferred to cell culture flask (Corning, USA) in Dulbecco's Modified Eagle's Medium supplemented with $10 \%$ fetal bovine serum (FBS) (Biological Industries, Israel), $1 \%$ Pen-Strep (Gibco, USA), and $1 \% \mathrm{~L}$-glutamine (Gibco, USA) and placed into the incubator at $37^{\circ} \mathrm{C}$ in a humidified incubator containing $5 \% \mathrm{CO}_{2}$. Cells from passage 2 were harvested during the first expansion period.

\section{Cryopreservation}

About $3 \times 10^{6} \mathrm{AD}$-MSCs at passage 2 were suspended in $1 \mathrm{ml}$ of cryoprotectant solution containing $10 \%$ dimethyl sulfoxide $\left(\mathrm{Me}^{2} \mathrm{SO}\right)$ (Sigma-Aldrich, USA)and $90 \%$ FBS (Biological Industries, Israel).The cell suspension was kept in freezing tube (Corning, USA), cooled to $80^{\circ} \mathrm{C}$ at a rate of $-1^{\circ} \mathrm{C} / \mathrm{min}$ in freezing container (Nalgene, USA), and then transferred to nitrogen tank for long-term storage. At each freeze-thaw cycle, the stem cell characteristics of AD-MSCs were evaluated (Table 4).

\section{Thawing and expansion}

AD-MSCs was taken from nitrogen tank and rapidly thawed in water bath kettle of $37^{\circ} \mathrm{C}$ and transferred to a $15 \mathrm{ml}$ centrifuge tube in $10 \times$ volume of PBS for washing twice. The thawed cells were cultivated and proliferated using the same protocol as described for primary expansion. AD-MSCs from passage 3 to 7 were harvested for cytotherapy during this expansion period. All the cells for cytotherapy were evaluated synchronously (Table 5).
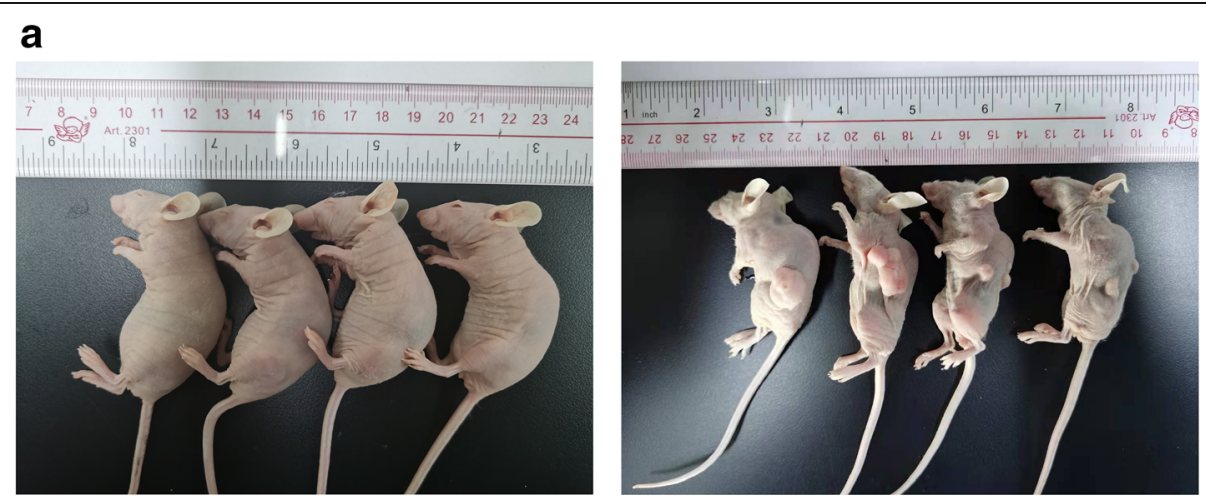

b
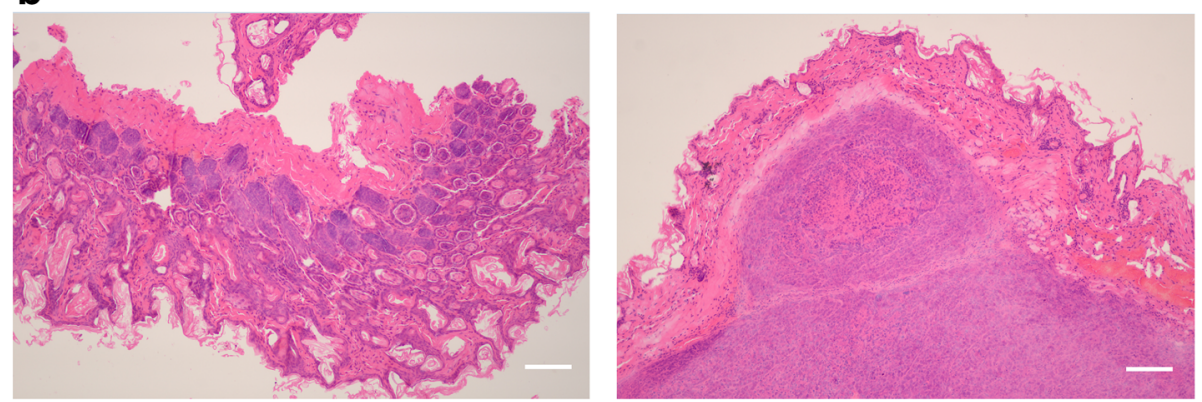

Fig. 6 Tumorigenicity evaluation of canine AD-MSCs in passage 5. a No tumor formation was observed in the AD-MSCs group within $40 \mathrm{~d}$ after subcutaneous injection in mice (arrow: visible tumor in Hela cells group). b Histopathological examination of hematoxylin and eosin staining in injection sites. No cell mass formation was observed in the AD-MSCs group. However, the HeLa cells injection site showed a subcutaneous mass. Scale bars, $100 \mu \mathrm{m}$ 
Table 4 In-process test and cryopreservation criteria

\begin{tabular}{lll}
\hline Specification & Expected & Methods \\
\hline Donor virology (RV, CDV, ICHV, CPV and CCV) & Negative & Elisa Kit \\
Viability & $\geq 90 \%$ & Trypan blue staining \\
Sterility & No growth & Microbiology culture \\
Mycoplasma & Negative & Culture \\
Endotoxin & $>0.5 \mathrm{EU} / \mathrm{mL}$ & Limulus Amebocyte Lysate \\
Phenotype (CD29, CD34, CD44, CD45 and CD90) & $\geq 95 \% \mathrm{CD} 29, \mathrm{CD} 34, \mathrm{CD} 90$ & Flow cytometry \\
Differentiation potential & $\leq 2 \%$ CD34, CD45 & Induction culture \\
\hline
\end{tabular}

\section{Characterization and quality control}

\section{Cell counts and viability assessment}

Accurate assessment of cell count and viability of ADMSCs by the trypan blue dye exclusion test using automatic cell counter (Countess, Invitrogen, USA). The viability was calculated using the following formula: number of trypan blue-negative cells/number of total cell cells $\times 100$.

\section{Flow cytometry analysis}

Cells were incubated with the following phycoerythrin (PE)-conjugated or fluorescein isothiocyanate (FITC)conjugated antibodies: anti-CD29-PE (cat.no.303,004; BioLegend), anti-CD34-PE (cat.no.ab23830; Abcam), anti-CD44- FITC (cat.no.MA1-10229; Invitrogen), antiCD45-FITC (cat.no.ab27287; Abcam), and anti-CD90-PE (cat.no.11-0900-81; Invitrogen) or their respective isotype controls. Cells were analyzed using a FACSCanto flow cytometry system (Beckman, USA). Data acquisition and analysis was performed with CytExpert.

\section{In vitro differentiation assessment}

In vitro adipogenic, osteogenic and chondrogenic differentiation were examined using MSCs Adipogenic Differentiation Kit (Cyanogen, China), Osteogenic Differentiation Kit and Chondrogenic Differentiation Kit (Cyanogen,
China) following the manufacturer's protocol for each kit. Adipogenic Differentiation Kit contains basic medium, fetal bovine serum, dexamethasone, insulin, IBMX and indomethacin. Osteogenic Differentiation Kit contains basic medium, fetal bovine serum, ascorbate, $\beta$ Glycerophosphate and dexamethasone. Chondrogenic Differentiation Kit contains basic medium, fetal bovine serum, ascorbate, dexamethasone, sodium Pyruvate, TGF$\beta 3$, insulin, transferrin and selenium. Cells were stained with Oil Red $\mathrm{O}$ solution to assess adipogenic differentiation, alizarin red solution to assess osteogenic differentiation and alcian blue solution to assess chondrogenic differentiation.

\section{Population Doubling Time (Td) estimation}

Cells were counted by automatic cell counter and cell population doubling time $(\mathrm{Td})$ was calculated using the following formula: $\mathrm{Td}=\mathrm{t} \times \lg 2 /(\operatorname{lgNt}-\operatorname{lgNo})$, where "No" refers to cell number after inoculation and "Nt" refers to cell number at $\mathrm{T}$ hour culture.

\section{Colony-forming unit-fibroblasts estimation}

AD-MSCs were seeded in 60-mm Petri dishes (100 cells/ dish) cultured for 10 days, and stained with crystal violet solution. The number of colonies was determined under a camera, and clusters of more than 50 cells were

Table 5 Final product release criteria

\begin{tabular}{|c|c|c|}
\hline Specification & Expected & Methods \\
\hline Cell counts & $1.0 \times 10^{6} / \mathrm{kg}$ & Automatic cell counter \\
\hline Viability & $\geq 90 \%$ & Trypan blue staining \\
\hline Sterility & No growth & Microbiology culture \\
\hline Mycoplasma & Negative & Culture \\
\hline Endotoxin & $>0.5 \mathrm{EU} / \mathrm{mL}$ & Limulus Amebocyte Lysate \\
\hline Phenotype (CD29, CD34, CD44, CD45 and CD90) & $\begin{array}{l}\geq 95 \% \text { CD29, CD34, CD90 } \\
\leq 2 \% \text { CD34, CD45 }\end{array}$ & Flow cytometry \\
\hline Differentiation potential & Osteogenesis, adipogenesis & Induction culture \\
\hline Karyotype analysis & 39 pairs of chromosomes & Giemsa staining \\
\hline Tumorigenicity & Negative & Injection into nude mice \\
\hline
\end{tabular}


considered colonies. The Colony-Forming unitfibroblasts(CFU-F)was calculated using the following formula: $\mathrm{CFU}-\mathrm{F}=$ colony number $/$ initial cell number $\mathrm{x}$ $100 \%$.

\section{Microbiology testing}

Mycoplasma, Bacterium and fungus examination were performed in accordance with methods set forth in the Chinese Veterinary Pharmacopoeia. Sterility test was performed by inoculating samples in two different sterile nutrient mediums, namely, Fluid Thioglycolate Medium and Soybean Casein Digest Medium. Mycoplasma detection was done by inoculating samples in Mycoplasma Agar Medium and Mycoplasma Broth Medium.

\section{Endotoxin testing}

Endotoxin levels were determined by the gel clot limulus amebocyte lysate test in accordance with methods set forth in the Chinese Veterinary Pharmacopoeia.

\section{Karyotype analysis}

Chromosomes were prepared and banded by the Gbanding technique according to standard methods. Following Giemsa staining, the numbers of chromosomes were calculated and analyzed.

\section{Tumorigenicity assay}

AD-MSCs and Hela (positive control) cells were delivered into the flank of 5-week-old female NOD/SCID mice, purchasing from Guangdong Experimental Animal Center. All mice were housed in a well-ventilated holding room with free access to food and water, and a 12/ $12 \mathrm{~h}$ light/dark cycle, with an ambient temperature of $20-25^{\circ} \mathrm{C}$. After 40 days, tumors were excised after anesthesia with the injection of $3 \%$ pentobarbital sodium $(0.1 \mathrm{ml} / 100 \mathrm{~g})$. Tumors were fixed by immersion in neutral buffered formalin and processed for standard hematoxylin and eosin staining.

\section{A case of cell therapy}

A 2-month-old male golden retriever was diagnosed with leukopenia caused by canine parvovirus in February 2019. Clinical examination showed the body temperature rose to 39.2 degrees, the pulse rate was 110 beats/minute and the breathing was 30 beats/minute. Further blood test showed a significant decrease in white blood cells and neutrophils. It was finally diagnosed as CPV passing the CPV test strip. The case was treated with routine antiviral therapy and fluid supplementation while canine AD-MSCs were intravenously transplanted. The stem cells $\left(1 \times 10^{6}\right.$ cells per kilogram of body weight $)$ were diluted in normal saline containing $1 \%$ canine serum albumin (Blood biotech, China) and transplanted into the sick dog once a day for 3 consecutive times. Biochemical indicators at 2, 3 days after treatment were tested to determine the treatment effect. Control group was another male golden retriever identified with parvovirus infection in the same litter. Clinical examination showed the body temperature rose to 38.5 degrees, the pulse rate was 110 beats/minute and the breathing was 22 beats/minute. The control case was treated with routine antiviral therapy and fluid supplementation.

\section{Statistical analysis}

SPSS 17.0 software (SPSS, Inc.) was used for statistical analysis. Values are expressed as the means \pm standard deviation. Statistical analysis was performed using oneway analysis of variance with the least-significant difference post hoc test. $P<0.05$ was considered to indicate a statistically significant difference.

\section{Abbreviations \\ AD-MSCs: Adipose-derived Mesenchymal stem cells; CCV: Canine coronaviruses; CDV: Canine distemper virus; CFU-F: Colony-Forming unit- fibroblasts; CPV: Canine parvovirus; DMEM: Dulbecco's Modified Eagle's Medium; FBS: Fetal bovine serum; FITC: Fluorescein isothiocyanate; ICHV: Infectious canine hepatitis virus; $\mathrm{Me}^{2} \mathrm{SO}$ : Dimethyl sulfoxide; MSCs: Mesenchymal stem cells; PE: Phycoerythrin; RV: Rabies virus; Td: Population doubling time}

\section{Acknowledgements}

Not applicable.

\section{Authors' contributions}

BYW and SFC designed the study. HNL and DSL performed the experiments and analysed the data. ZSC collected the samples. All authors read and approved the final manuscript.

\section{Funding}

This study has been supported by the Natural Science Foundation of Guangdong Province (grant no. 2017A030313171 and 2020A1515011110). The funder had no role in study design, data collection and analysis, interpretation of data or writing of the manuscript.

Availability of data and materials

The datasets used and/or analysed during the current study are available from the corresponding author upon reasonable request.

\section{Ethics approval and consent to participate}

All procedures in the present study were approved by the Animal Ethics Committee of Foshan University and written informed consent was obtained from all donors.

Consent for publication

Not applicable.

\section{Competing interests}

The authors declare that they have no competing interests.

\section{Author details}

${ }^{1}$ School of Life Science and Engineering, Foshan University, 528231 Foshan, Guangdong, China. ${ }^{2}$ VetCell Biotechnology Company Limited, 528231

Foshan, Guangdong, China. 
Received: 21 August 2020 Accepted: 4 February 2021 Published online: 01 March 2021

\section{References}

1. Friedenstein AJ, Petrakova KV, Kurolesova Al, Frolova GP. Heterotopic of bone marrow. Analysis of precursor cells for osteogenic and hematopoietic tissues. Transplantation. 1968;6(2):230-47.

2. Pittenger MF, Mackay AM, Beck SC, Jaiswal RK, Douglas R, Mosca JD, Moorman MA, Simonetti DW, Craig S, Marshak DR. Multilineage potential of adult human mesenchymal stem cells. Science. 1999;284(5411):143-7.

3. Gong W, Han Z, Zhao H, Wang Y, Wang J, Zhong J, Wang B, Wang S, Wang $Y$, Sun $L$, et al. Banking human umbilical cord-derived mesenchymal stromal cells for clinical use. Cell Transplant. 2012;21(1):207-16.

4. Alfaifi M, Eom YW, Newsome PN, Baik SK. Mesenchymal stromal cell therapy for liver diseases. J Hepatol. 2018;68(6):1272-85.

5. Si YL, Zhao YL, Hao HJ, Fu XB, Han WD. MSCs: Biological characteristics, clinical applications and their outstanding concerns. Ageing Res Rev. 2011; 10(1):93-103.

6. Guess AJ, Daneault B, Wang R, Bradbury H, La Perle K, Fitch J, Hedrick SL, Hamelberg E, Astbury C, White P, et al. Safety Profile of Good Manufacturing Practice Manufactured Interferon gamma-Primed Mesenchymal Stem/ Stromal Cells for Clinical Trials. Stem Cells Transl Med. 2017:6(10):1868-79.

7. Couto PS, Shatirishvili G, Bersenev A, Verter F. First decade of clinical trials and published studies with mesenchymal stromal cells from umbilical cord tissue. Regen Med. 2019;14(4):309-19.

8. Wilson JG, Liu KD, Zhuo H, Caballero L, McMillan M, Fang X, Cosgrove K, Vojnik $\mathrm{R}$, Calfee CS, Lee JW, et al. Mesenchymal stem (stromal) cells for treatment of ARDS: a phase 1 clinical trial. Lancet Respir Med. 2015;3(1):24-32.

9. Shakhbazau A, Potapnev M. Autologous mesenchymal stromal cells as a therapeutic in ALS and epilepsy patients: Treatment modalities and ex vivo neural differentiation. Cytotherapy. 2016;18(10):1245-55.

10. Lin HY, Fujita N, Endo K, Morita M, Takeda T, Nakagawa T, Nishimura R. Isolation and Characterization of Multipotent Mesenchymal Stem Cells Adhering to Adipocytes in Canine Bone Marrow. Stem Cells Dev. 2017;26(6): $431-40$

11. Dragoo JL, Chang W. Arthroscopic Harvest of Adipose-Derived Mesenchymal Stem Cells From the Infrapatellar Fat Pad. Am J Sports Med. 2017;45(13):3119-27.

12. Gokcinar-Yagci B, Ozyuncu O, Celebi-Saltik B. Isolation, characterisation and comparative analysis of human umbilical cord vein perivascular cells and cord blood mesenchymal stem cells. Cell Tissue Bank. 2016;17(2):345-52.

13. Yamada Y, Nakamura-Yamada S, Kusano K, Baba S. Clinical Potential and Current Progress of Dental Pulp Stem Cells for Various Systemic Diseases in Regenerative Medicine: A Concise Review. Int J Mol Sci. 2019;20(5):1132.

14. Pelekanos RA, Sardesai VS, Futrega K, Lott WB, Kuhn M, Doran MR. Isolation and Expansion of Mesenchymal Stem/Stromal Cells Derived from Human Placenta Tissue. J Vis Exp. 2016(112)

15. Borghesi J, Ferreira LM, Mario LC, de Almeida DAA, Silveira RA, Giancoli KCDS, Assunpcao FF, Miglino MA, Oliveira CA, Oliveira FP. Canine amniotic membrane mesenchymal stromal/stem cells: Isolation, characterization and differentiation. Tissue Cell. 2019;58:99-106.

16. Wang Z, Sun D. Adipose-Derived Mesenchymal Stem Cells: A New Tool for the Treatment of Renal Fibrosis. Stem Cells Dev. 2018;27(20):1406-11.

17. Kumar H, Ha DH, Lee EJ, Park JH, Shim JH, Ahn TK, Kim KT, Ropper AE, Sohn $\mathrm{S}, \mathrm{Kim} \mathrm{CH}$, et al. Safety and tolerability of intradiscal implantation of combined autologous adipose-derived mesenchymal stem cells and hyaluronic acid in patients with chronic discogenic low back pain: 1-year follow-up of a phase I study. Stem Cell ResTher. 2017:8(1):262.

18. Fang J, Wei $Y$, Teng $X$, Zhao S, Hua J. Immortalization of canine adiposederived mesenchymal stem cells and their seminiferous tubule transplantation. J Cell Biochem. 2018;119(4):3663-70.

19. Gugjoo MB, Amarpal, Chandra V, Wani MY, Dhama K, Sharma GT. Mesenchymal Stem Cell Research in Veterinary Medicine. Curr Stem Cell Res Ther. 2018;13(8):645-57.

20. Zhang BY, Wang BY, Li SC, Luo DZ, Zhan X, Chen SF, Chen ZS, Liu CY, Ji HQ, Bai YS, et al. Evaluation of the Curative Effect of Umbilical Cord Mesenchymal Stem Cell Therapy for Knee Arthritis in Dogs Using Imaging Technology. Stem Cells Int. 2018;2018:1983025.

21. Olsen A, Johnson V, Webb T, Santangelo KS, Dow S, Duerr FM. Evaluation of Intravenously Delivered Allogeneic Mesenchymal Stem Cells for Treatment of Elbow Osteoarthritis in Dogs: A Pilot Study. Vet Comp Orthop Traumatol. 2019:32(3):173-81.

22. Kim HJ, Li Q, Song WJ, Yang HM, Kim SY, Park SC, Ahn JO, Youn HY. Fibroblast growth factor-1 as a mediator of paracrine effects of canine adipose tissue-derived mesenchymal stem cells on in vitro-induced insulin resistance models. BMC Vet Res. 2018;14(1):351.

23. Perez-Merino EM, Uson-Casaus JM, Duque-Carrasco J, Zaragoza-Bayle C, Marinas-Pardo L, Hermida-Prieto M, Vilafranca-Compte M, Barrera-Chacon R, Gualtieri M. Safety and efficacy of allogeneic adipose tissue-derived mesenchymal stem cells for treatment of dogs with inflammatory bowel disease: Endoscopic and histological outcomes. Vet J. 2015;206(3):391-7.

24. Villatoro AJ, Hermida-Prieto M, Fernandez V, Farinas F, Alcoholado C, Rodriguez-Garcia Ml, Marinas-Pardo L, Becerra J. Allogeneic adipose-derived mesenchymal stem cell therapy in dogs with refractory atopic dermatitis: clinical efficacy and safety. Vet Rec. 2018;183(21):654.

25. Guercio A, Di Marco P, Casella S, Cannella V, Russotto L, Purpari G, Di Bella S, Piccione $\mathrm{G}$. Production of canine mesenchymal stem cells from adipose tissue and their application in dogs with chronic osteoarthritis of the humeroradial joints. Cell Biol Int. 2012;36(2):189-94.

26. Kriston-Pal E, Czibula A, Gyuris Z, Balka G, Seregi A, Sukosd F, Suth M, Kiss-Toth E, Haracska L, Uher F, et al. Characterization and therapeutic application of canine adipose mesenchymal stem cells to treat elbow osteoarthritis. Can J Vet Res. 2017;81(1):73-8.

27. Escalhao C, Ramos IP, Hochman-Mendez C, Brunswick T, Souza S, Gutfilen B, Dos SGR, Coelho-Sampaio T. Safety of Allogeneic Canine Adipose Tissue-Derived Mesenchymal Stem Cell Intraspinal Transplantation in Dogs with Chronic Spinal Cord Injury. Stem Cells Int. 2017:2017:3053759

28. Jossen V, van den Bos C, Eibl R, Eibl D. Manufacturing human mesenchymal stem cells at clinical scale: process and regulatory challenges. Appl Microbiol Biotechnol. 2018;102(9):3981-94.

29. Lechanteur C, Briquet A, Giet O, Delloye O, Baudoux E, Beguin Y. Clinicalscale expansion of mesenchymal stromal cells: a large banking experience. J Transl Med. 2016:14(1):145.

30. Chen DC, Chen LY, Ling QD, Wu MH, Wang CT, Suresh KS, Chang Y, Munusamy MA, Alarfaij AA, Wang HC, et al. Purification of human adiposederived stem cells from fat tissues using PLGA/silk screen hybrid membranes. Biomaterials. 2014;35(14):4278-87.

31. Gentile P, Calabrese C, De Angelis B, Pizzicannella J, Kothari A, Garcovich S Impact of the Different Preparation Methods to Obtain Human AdiposeDerived Stromal Vascular Fraction Cells (AD-SVFs) and Human AdiposeDerived Mesenchymal Stem Cells (AD-MSCs): Enzymatic Digestion Versus Mechanical Centrifugation. Int J Mol Sci. 2019;20(21):5471.

32. Phinney DG, Galipeau J. Manufacturing mesenchymal stromal cells for clinical applications: A survey of Good Manufacturing Practices at U.S. academic centers. Cytotherapy. 2019;21(7):782-92

33. Yin JQ, Zhu J, Ankrum JA. Manufacturing of primed mesenchymal stromal cells for therapy. Nat Biomed Eng. 2019:3(2):90-104.

34. Rojewski MT, Lotfi R, Gjerde C, Mustafa K, Veronesi E, Ahmed AB, Wiesneth M, Korper S, Sensebe L, Layrolle P, et al. Translation of a standardized manufacturing protocol for mesenchymal stromal cells: A systematic comparison of validation and manufacturing data. Cytotherapy. 2019;21(4): 468-82.

35. Dominici M, Le Blanc K, Mueller I, Slaper-Cortenbach I, Marini F, Krause D, Deans R, Keating A, Prockop D, Horwitz E. Minimal criteria for defining multipotent mesenchymal stromal cells. The International Society for Cellular Therapy position statement. Cytotherapy. 2006;8(4):315-7.

36. Galvez P, Clares B, Bermejo M, Hmadcha A, Soria B. Standard requirement of a microbiological quality control program for the manufacture of human mesenchymal stem cells for clinical use. Stem Cells Dev. 2014;23(10):1074-83.

37. Van Pham P, Truong NC, Le PT, Tran TD, Vu NB, Bui KH, Phan NK. Isolation and proliferation of umbilical cord tissue derived mesenchymal stem cells for clinical applications. Cell Tissue Bank. 2016;17(2):289-302.

38. Xu L, Liu Y, Sun Y, Wang B, Xiong Y, Lin W, Wei Q, Wang H, He W, Wang B, et al. Tissue source determines the differentiation potentials of mesenchymal stem cells: a comparative study of human mesenchymal stem cells from bone marrow and adipose tissue. Stem Cell Res Ther. 2017; 8(1):275.

39. Silva JD, Lopes-Pacheco M, Paz A, Cruz FF, Melo EB, de Oliveira MV, Xisto DG, Capelozzi VL, Morales MM, Pelosi P, et al. Mesenchymal Stem Cells From Bone Marrow, Adipose Tissue, and Lung Tissue Differentially Mitigate 
Lung and Distal Organ Damage in Experimental Acute Respiratory Distress Syndrome. Crit Care Med. 2018;46(2):e132-40.

40. Zhan XS, El-Ashram S, Luo DZ, Luo HN, Wang BY, Chen SF, Bai YS, Chen ZS, Liu CY, Ji HQ. A Comparative Study of Biological Characteristics and

Transcriptome Profiles of Mesenchymal Stem Cells from Different Canine Tissues. Int J Mol Sci. 2019;20(6):1485.

\section{Publisher's Note}

Springer Nature remains neutral with regard to jurisdictional claims in published maps and institutional affiliations.

Ready to submit your research? Choose BMC and benefit from:

- fast, convenient online submission

- thorough peer review by experienced researchers in your field

- rapid publication on acceptance

- support for research data, including large and complex data types

- gold Open Access which fosters wider collaboration and increased citations

- maximum visibility for your research: over $100 \mathrm{M}$ website views per year

At $\mathrm{BMC}$, research is always in progress.

Learn more biomedcentral.com/submissions 